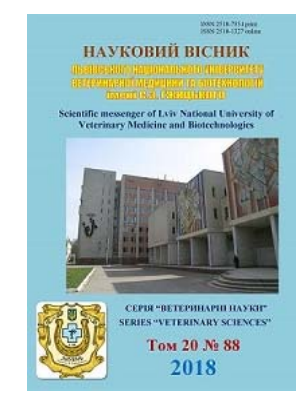

Науковий вісник Дьвівського національного університету ветеринарної медицини та біотехнологій імені С.3. Гжицького

\author{
Scientific Messenger of Lviv National University \\ of Veterinary Medicine and Biotechnologies
}

UDC $631.57: 664.126(4778)$

\title{
Veterinary and sanitary assessment of quality and safety of meat and meat products in the marshes of LLC "Riton" Vinnytsa
}

\author{
V.A. Kotelevych \\ Zhytomyr National Agroecological University, Zhytomyr, Ukraine
}

Article info

Received 10.07.2018

Received in revised form 13.08 .2018

Accepted 15.08.2018

Zhytomyr National Agroecological University, Korolova Str., 39 , Zhytomyr, 10025, Ukraine. Tel.: +38-067-456-23-80

E-mail:valya.kotelevich@ukr.net
Kotelevych, V.A. (2018). Veterinary and sanitary assessment of quality and safety of meat and meat products in the marshes of LLC "Riton" Vinnytsa. Scientific Messenger of Lviv National University of Veterinary Medicine and Biotechnologies, 20(88), 24-28. doi: 10.32718/nvlvet8804

The purpose of our research was to study the environmental aspects of the quality and safety of meat and meat products in the conditions of Ltd "Ryton" Vinnytsya and the measures applied in this subsidiary for the observance of proper hygienic and production practices (GHP/GMP) in their production as a guarantor of environmental security. The results of the veterinary and sanitary estimation of meat and meat products are reported according to the data of the reporting documentation of Ltd Ryton Vinnytsia (20152017), expert opinions of the Vinnytsia Regional State Veterinary Laboratory and Khmelnytsky Interdistrict State Laboratory of Veterinary Medicine (2018) on indicators security. The main cause of detoxification of byproducts was invasive and non-contagious diseases, in particular: liver - cirrhosis, fasciolysis and abscesses; kidneys - jade heart-traumatic pericarditis; udder-mastitis, lungs - pneumonia, pleurisy, aspiration with food and blood. According to safety indicators, there is a lack of pesticides (the mass fraction of HCCh gamma-isomer, DDT and its metabolites, DDVF, chlorophos, metaphys, carbophos, basidins), toxic elements (lead, cadmium, arsenic, mercury, copper, zinc), mycotoxins, antibiotics; Radiological and microbiological parameters in meat and meat samples were also within regulatory requirements and safe for consumption. The introduction of proper hygienic and production practices allowed Vinnitsa LLC to complete the certification process under the international program FSSC 22000 "Food Safety Management" and obtain the Certificates The HACCP Management System of CCM MS Standart HACCP and ISO 22000: 2007 Food Safety Management Systems, Requirements for any Organisation in the Food Chain. The performed researches prove the theoretical and practical justification of the necessity of monitoring research on the quality and safety of livestock products, the observance of proper hygienic and production practices $(G H P / G M P)$ taking into account the international program FSSC 22000 "Food Safety Management", - the need to strengthen preventive measures by doctors of veterinary medicine invasive and non-contagious diseases of cattle.

Key words: meat, safety, invasive and non-contagious diseases, pesticides, hygienic and industrial practices $(G H P / G M P)$.

\section{Ветеринарно-санітарна оцінка якості та безпеки м'яса і м'ясопродуктів в умовах ТОВ "Ритон" Вінниця}

\author{
В.А. Котелевич
}

Житомирський національний агроекологічний університет, м. Житомир, Украӥна

\footnotetext{
Метою наших досліджень було вивчити екологічні аспекти якості та безпеки м'яса і м'ясопродуктів в умовах ТОВ “Ритон” Вінниця та заходи, які застосовуються на иьому підприємстві щодо дотримання належної гігієнічної $і$ виробничої практик $(G H P / G M P)$ при їхньому виробництві як гаранта екологічної безпеки. Наведено результати ветеринарно-санітарної оцінки м'яса $i$ м'ясопродуктів за даними звітної документації ТОВ “Ритон” Вінниця (2015-2017), експертних висновків Вінницької регіональної державної лабораторії ветеринарної медицини та Хмельницької міжрайонної державної лабораторії ветеринарної медицини (2018 р.) щодо показників безпеки. Основною причиною вибраковки субпродуктів були інвазійні та незаразні хвороби, зокрема: печінки - цироз, фасиіольоз та абсиеси; нирок - нефрит; серия - травматичний перикардит; вимені-мастит, легень - пневмонія, плеврит, аспірація кормом та кров'ю. За показниками безпеки встановлена відсутність пестицидів (масова частка ГХЦГ гама-
} 
ізомеру, ДДТ та його метаболіти, ДДВФ, хлорофосу, метафосу, карбофосу, базидину), токсичних елементів (Свинеиь, Кадмій, Арсен, Ртуть, Мідь, Цинк), мікотоксинів, антибіотиків; радіологічні та мікробіологічні показники у зразках м'яса $i$ м'ясопродуктів також були в межах нормативних вимог та безпечними для споживання. Введення належної гігієнічної і виробничої практик дало можливість ТОВ “Ритон” Вінниця завершити процес сертифікації за міжнародною програмою FSSC 22000 “Менеджмент безпеки харчових продуктів” і отримати сертифікати The HACCP Management System of CCM MS Standart HACCP ma ISO 22000:2007 Food Safety Management Systems, Requirements for any Organisation in the Food Chain. Buконані дослідження доводять теоретичне та практичне обтрунтування необхідності проведення моніторингових досліджень якості $і$ безпеки тваринницької продукиї, дотримання належної гігієнічної $і$ виробничої практик (GHP/GMP) з урахуванням міжнародної програми FSSC 22000 “Менеджмент безпеки харчових продуктів”, встановлена необхідність посилення заходів профілактики лікарями ветеринарної медицини інвазійних та незаразних захворювань великої рогатої худоби.

Ключові слова: м'ясо, безпека, інвазійні і незаразні хвороби, пестициди, гігієнічна і виробнича практики (GHР/GMP).

\section{Ветуп}

Для інтеграції України в світове економічне товариство необхідно спрямувати зусилля на випуск якісної і безпечної продукції, що неможливо без дотримання загальних принципів (Ukaz prezydenta Ukrai'ny vid 15.06.2015. №951/2005).

Одним із найбільш відомих і поширених інструментів управління безпекою харчових продуктів $є$ HACCP (Hazard Analisis Critical Control Point), що пов'язує усі заходи для отримання якісної продукції (Jakubchak et al., 2005; Khimich et al., 2017; Bogatko et al., 2018). Проте НАССР потребує підтримки іншими засобами контролю. Виробництво безпечних харчових продуктів передбачає, щоб система НАССР здійснювалася на основі програм-передумов. Підприємство, діяльність якого пов'язана із виробництвом харчових продуктів, повинно забезпечувати необхідні умови для захисту їх на час перебування на даному виробництві. Це зазвичай забезпечує застосування належної гігієнічної та виробничої практик (GHP/GMP).

Все вищенаведене $\epsilon$ актуальним, адже забруднення навколишнього середовища антропогенного походження на початок XXI століття досягло такого масштабу, що починає бути небезпечним для існування людини як біологічного виду. До найактуальніших проблем сьогодення належать екологічні: організація раціонального використання природних ресурсів, надійний захист сільськогосподарських тварин, безпечне споживання продуктів тваринництва (Kotelevych et al., 2010; Kotelevych, 2017; 2018).

Показники безпеки продовольчої продукції - це науково обгрунтовані гранично допустимі межі вмісту шкідливих для здоров'я i життя людини компонентів чи речовин хімічного, біологічного, радіаційного та будь-якого іншого походження, перевищення яких призводить до шкідливого впливу на здоров'я людини.

Сучасне законодавство України щодо якості продовольчої сировини та харчової продукції підвищує вимоги безпеки до рівня, що узгоджується з нормами країн ЄС. 320 вересня 2016 року вступив у дію Закон України "Про основні принципи та вимоги до безпечності та якості харчових продуктів”, згідно 3 яким відповідальність за безпечність та якість харчових продуктів покладено на виробника (Kos'janchuk, 2016). Отже, однією із причин реалізації недоброякісних харчових виробів є недосконалість ветеринарно- санітарного контролю в умовах виробництва та реалізації продукції.

Це вимагає проведення моніторингових досліджень якості і безпеки тваринницької продукції, дотримання належної гігієнічної і виробничої практик (GHP/GMP) 3 урахуванням міжнародної програми FSSC 22000 "Менеджмент безпеки харчових продуктів".

Незважаючи на те, що м'ясо $є$ незамінним харчовим продуктом, воно може бути джерелом шкідливих речовин та заразних захворювань людини.

Харчові отруєння - гострі (рідше хронічні) не контагіозні хвороби, що виникають внаслідок споживання м'яса i м'ясних продуктів, засіяних різними видами мікроорганізмів або тих, що містять токсичні для організму речовини мікробної або немікробної природи. Щороку сотні мільйонів людей страждають від захворювань харчового походження (Jakubchak, 2011).

Глобалізація торгівлі перетворила нешкідливість харчових продуктів у міжнародну проблему. Санітарна нешкідливість харчових продуктів повинна відстежуватися по всьому харчовому ланцюгу “від ферми - до столу”, а лікарі ветеринарної медицини відповідають за провідну ланку в санітарній нешкідливості харчових продуктів тваринного походження. Саме тому нова європейська Регламентація 3 нешкідливості продуктів харчування передбачає науковий аналіз в оцінці ризиків щодо харчових продуктів, який повинен проводитися незалежно і об'єктивно. Щоб гарантувати високий рівень захисту населення від хвороб харчового походження, особливо негайним $€$ інтеграція виробництва екологічно чистих кормів, забезпечення відповідних санітарно-гігієнічних умов утримання тварин, профілактичні заходи щодо захворювання тварин, визначення усіх потенційних ризиків на шляху “від ферми - до столу” та вміле управління ними. Критичні контрольні пункти аналізу практики на підприємстві на належному рівні.

За даними опитування Національних ветеринарних служб членів Регіональної комісії МЕБ у Європі, нешкідливість харчових продуктів повинна бути пріоритетним напрямком діяльності. При цьому біологічні чинники визнаються найбільш важливими, а за ними - чинники хімічного походження. Завдання ветеринарної служби - захист здоров'я населення від ризиків, що пов'язанні з вживанням недоброякісних продуктів. 
Беручи до уваги вищезазначене, метою наших досліджень було вивчити екологічні аспекти якості та безпеки м'яса і м'ясопродуктів в умовах ТОВ “Ритон” Вінниця та заходи, які застосовуються на цьому підприємстві щодо дотримання належних гігієнічної $\mathrm{i}$ виробничої практик (GHP/GMP) при їхньому виробництві як гарантів екологічної безпеки.

\section{Матеріал і методи досліджень}

Матеріалом для проведення моніторингу були: нормативно-технічна документація, звітна документація, експертні висновки Вінницької регіональної державної лабораторії ветеринарної медицини та Хмельницької міжрайонної державної лабораторії ветеринарної медицини.

Матеріалом для власних досліджень були об'єкти ветеринарно-санітарного контролю та нагляду цього підприємства, зразки м'яса і субпродуктів. В умовах ТОВ "Ритон” Вінниця вивчали отримання продуктів забою ВРХ за вимогами належної гігієнічної та виробничої практик (GHP/GMP); проводили комплексну ветеринарно-санітарну експертизу продуктів забою великої рогатої худоби за схемою:

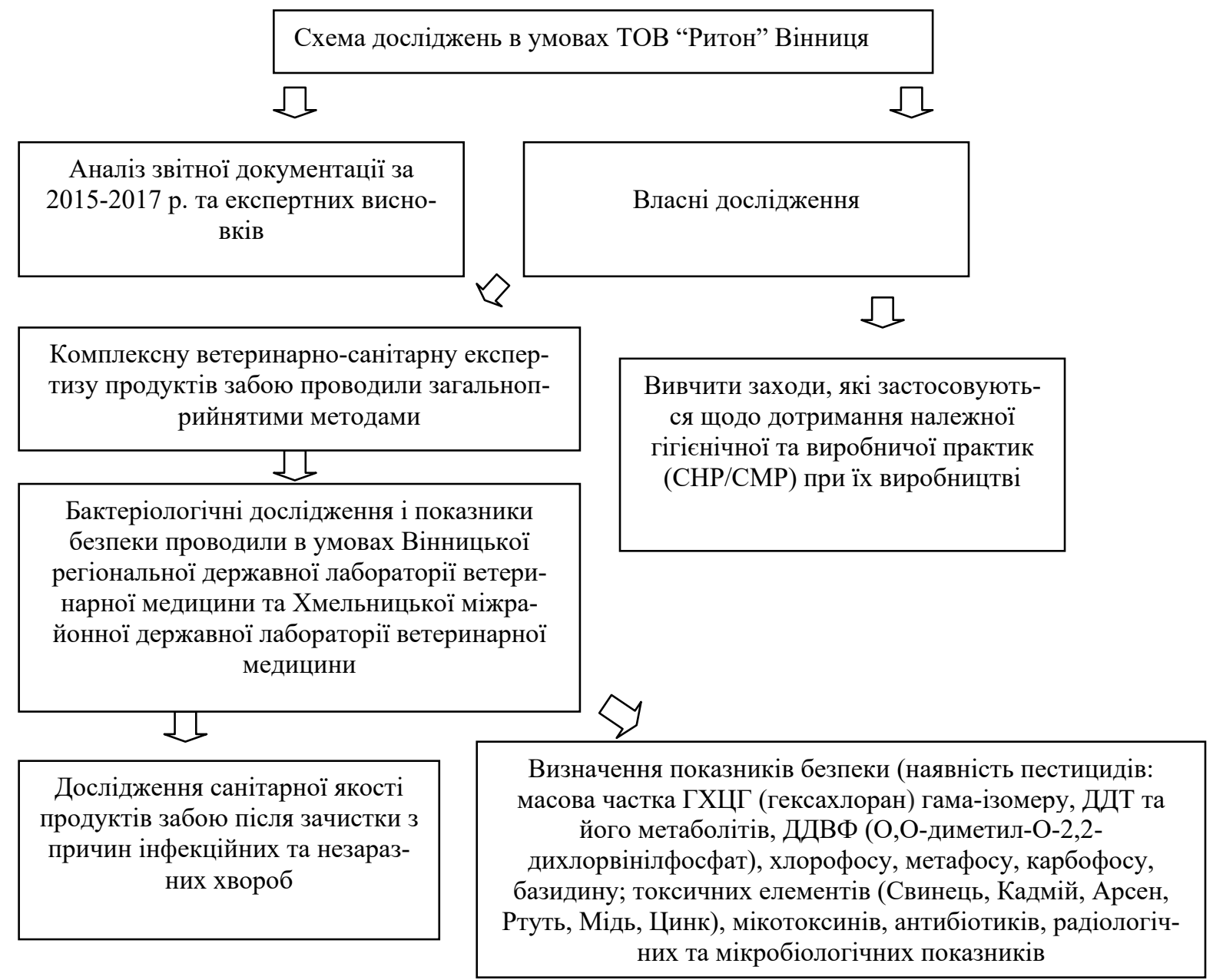

Рис. 1. Схема досліджень в умовах ТОВ “Ритон” Вінниця

\section{Результати та їх обговорення}

ТОВ “Ритон” Вінниця - це суб'єкт господарювання із завершеним виробничим циклом, що здійснює забій великої рогатої худоби, переробку м'яса та інших продуктів забою, їхнє зберігання та реалізацію відповідно до чинних нормативноправових актів. У своїй діяльності підприємство використовує нормативні документи: стандарти, технологічні інструкції, правила тощо. Воно розташоване, побудоване і обслуговується 3 дотриманням основних ветеринарно-санітарних норм; план руху продуктів забою тварин виключає контамінацію сировини i готової продукції.
Підприємство здійснює контроль постачальників за наявності ефективних програм належних гігієнічної та виробничої практик (GHP/GMP) на місцях.

Діяльність ТОВ “Ритон” Вінниця пов'язана 3 утриманням, транспортуванням, забоєм великої рогатої худоби, а також з виробництвом, переробкою, зберіганням, транспортуванням та реалізацісю продуктів забою.

Спеціалістом ветеринарної медицини обов'язково проводиться передзабійний ветеринарний огляд тварин, клінічне обстеження перед відправкою на ТОВ “Ритон” Вінниця та безпосередньо перед забоєм на забійному підприємстві.

Забійних тварин транспортують на ТОВ "Ритон” 
Вінниця таким чином, щоб вони не зазнавали страждань, не отримували зайвого забруднення або стресу, 3 виконанням принципу простежуваності щодо проходження тварин. Транспортні засоби, що використовуються для перевезення забійних тварин, сконструйовані таким чином, щоб тварин можна було легко завантажувати та вивантажувати $з$ мінімальним ризиком травмування; забруднення екскрементами, що $є$ на підлозі, зводяться до мінімуму; забезпечується належна вентиляція. Транспортні засоби, що використовуються для транспортування тварин до підприємства, утримуються в належному санітарному стані: чистяться та дезінфікуються одразу ж після розвантаження тварин.

Сировиною для даного підприємства $\epsilon$ велика рогата худоба, яка приймається на забій 3 урахуванням вимог "Правил передзабійного ветеринарного огляду тварин і післязабійної ветсанекспертизи м'яса та м'ясних продуктів" (2002) і за наявності усіх ветеринарних документів (Ветеринарне свідоцтво форма № 1 або довідка, відомість переміщення і паспорт на тварину). Уся худоба, яка надходить для забою на ТОВ "Ритон" Вінниця, підлягає передзабійному утриманню на території скотобази впродовж 24 годин для звільнення шлунково-кишкового тракту від вмісту. Тваринам надають вільний водопій, який припиняють за 3 години до забою.

Групи тварин, які під час передзабійного огляду визнані здоровими і придатними для забою, але належали до різних вікових груп, систем вирощування, на ТОВ “Ритон” Вінниця піддаються забою та розбираються окремо.

Будь-яка тварина, яка має забруднення зовнішніх покривів, перед наданням дозволу на прохід до приміщення забою очищується до рівня, необхідного для зменшення небезпеки забруднення м'яса, території, де відбувається забій та розбирання туш.

Для підтвердження придатності необроблених харчових продуктів тваринного походження для споживання людиною на м'ясопереробному підприємстві ТОВ “Ритон” Вінниця використовуються клейма.

Все обладнання ТОВ “Ритон” Вінниця сконструйоване і змонтоване відповідно до чинних санітарних вимог; є графіки профілактичного ремонту та калібрування.

Усі заходи чищення і прибирання описані і виконуються згідно графіку. На підприємстві всі працівники, що відвідують виробничі зони, чітко дотримуються заходів особистої гігієни. Адже всі вони проходять навчання з питань особистої гігієни, GHP/GMP, чищення та прибирання, безпеки праці та їх значення в програмі НАССР, результати якого реєструються.

Для запобігання забрудненню продуктів забою тварин шкідливими хімічними речовинами (мийні й дезінфекційні засоби, фуміганти, отрути чи приманки, що використовуються в приміщенні та навколо) в доступних місцях вивішені інструкції з їх застосування.

Вся сировина та продукція зберігається у належних санітарних умовах 3 дотриманням відповідної температури та вологості.
Всі партії продуктів забою тварин мають належне маркування, розроблена система відкликання продукції. На підприємстві діє ефективна програма дезінсекціï.

Для підтвердження здатності ТОВ “Ритон” Вінниця випускати безпечну продукцію, нами була складена система оцінки, 3 якою ми ознайомили працівників. Ми вивчили план-схему підприємства, щоб 3'ясувати рух продукту, послідовність операцій та простежити, які побічні продукти отримують.

Оскільки провести аналіз усіх складових складно, нами проведено аналіз небезпек (ризиків) з застосуванням дерева рішень для вирішення ККТ.

Проведений нами аналіз ветеринарно-санітарних показників якості тваринницької сировини, яка надходила на ТОВ "Ритон” Вінниця впродовж 20152017 pp., показав, що вибраковується значна іiі кількість. Аналіз причин вибраковки цих продуктів встановив, що це інвазійні та незаразні хвороби, зокрема: печінки - цироз, фасціольоз та абсцеси; нирок - нефрит; серця - травматичний перикардит; вимені - мастит, легень - пневмонія, плеврит, аспірація кормом та кров'ю.

Дослідження санітарної якості продуктів забою (печінка, легені, серце), отриманих після зачистки 3 вищезазначених причин показали, що загальна обсімененість цих продуктів порівняно 3 такими ж, які отримані від здорових тварин, значно вища. Зокрема, загальна обсімененість печінки, яка вибраковується 3 причин фасціольозу вища, ніж в цьому ж органі, отриманому від здорових тварин, на $84,0 \%, 3$ причин абсцесів - на 101,7\%, цирозу - на 100\%. Порівняльний аналіз обсімененості печінки, легень і серця показує, що найбільш обсімененими були печінка і легені, дещо менше - серце. 3 санітарно показової мікрофлори було визначено лише E. coli та клебсіели, тоді як сальмонели і протей були відсутні у всіх досліджуваних зразках.

Проведені дослідження зразків м'яса i м'ясопродуктів ТОВ “Ритон” Вінниця за показниками безпеки в умовах Вінницької регіональної державної лабораторії ветеринарної медицини та Хмельницької міжрайонної державної лабораторії ветеринарної медицини у 2018 році згідно 3 “Обов”язковим мінімальним переліком досліджень сировини, продукції тваринного та рослинного походження, комбікормової сировини, комбікормів, вітамінних препаратів та ін." встановили відсутність пестицидів (масова частка ГХЦГ гама-ізомеру, ДДТ та його метаболіти, ДДВФ, хлорофосу, метафосу, карбофосу, базидину), токсичних елементів (Свинець, Кадмій, Арсен, Ртуть, Мідь, Цинк), мікотоксинів, антибіотиків; радіологічні та мікробіологічні показники також були в межах нормативних вимог $\mathrm{i}$ вони $є$ безпечними для споживачів.

Введення належної гігієнічної і виробничої практик дало можливість ТОВ “Ритон” Вінниця завершити процес сертифікації за міжнародною програмою FSSC 22000 "Менеджмент безпеки харчових продуктів" i отримати сертифікати The HACCP Management System of CCM MS Standart HACCP та ISO 22000:2005 Food Safety Management Systems, Requirements for any 
Organisation in the Food Chain. В основі цих сертифiкатів - системний підхід, що передбачає збереження безпеки харчових продуктів на кожному етапі технологічного процесу (“від лану - до столу”).

Таким чином, планування процесу виробництва, прийом сировини і матеріалів, технологічні процеси, упаковка і маркування та контроль якості продуктів забою на ТОВ "Ритон” Вінниця відбуваються на належному рівні за вимогами міжнародних стандартів.

\section{Висновки}

1. Підприємство ТОВ “Ритон” Вінниця дотримується заходів належної гігієнічної практики (GHP/GMP) - гаранта екологічної безпеки продуктів забою тварин. За показниками безпеки усі продукти забою відповідали нормативним вимогам.

2. Виконані дослідження доводять теоретичне та практичне обгрунтування необхідності проведення моніторингових досліджень якості і безпеки тваринницької продукції, дотримання належних гігієнічної і виробничої практик (GHP/GMP) 3 урахуванням міжнародної програми FSSC 22000 "Менеджмент безпеки харчових продуктів".

3. Встановлена необхідність посилення заходів профілактики лікарями ветеринарної медицини інвазійних та незаразних захворювань великої рогатої худоби.

Перспективи подальших досліджень полягають у продовженні моніторингових досліджень якості та безпеки харчових продуктів, вивчення способів виробництва харчових продуктів в Житомирському регіоні, формування обізнаності виробників щодо застосування системи контролю якості сировини на всіх ланках виробництва харчового ланцюга для гарантування якості та безпечності харчової продукції.

\section{References}

Bogatko, N., Bogatko, L., Salata, V., Frejuk, D., \& Savchuk, G. (2018). Provision of security of milk and dairy products in Ukraine's profitabilized enterprises. Scientific Messenger of Lviv National University of Veterinary Medicine and Biotechnologies. 20(83), 8387. doi: $10.15421 /$ nvlvet8316.
Kos'janchuk, N.Y. (2016). Normatyvno-pravovi akty shhodo bezpechnosti i jakosti harchovyh produktiv. Naukovyj visnyk LNUVMB im. S.Z. Gzhyc'kogo, 18, 3(70), 150-152. doi:10.15421/nvlvet7035 (in Ukrainian).

Kotelevych, V.A., Fedotov, V.S., \& Stoljarenko, O.V. (2010). Shhodo jakosti i bezpechnosti m'jasa i m'jasnyh produktiv na rynkah Zhytomyrshhyny. Veterynarna medycyna Ukrai'ny, 8, 21-23 (in Ukrainian).

Kotelevych, V.A. (2017). Veterynarno-sanitarna ocinka jakosti ta bezpeky harchovyh produktiv u Zhytomyrs'komu regioni. Naukovyj visnyk LNUVMB im. S.Z. Gzhyc'kogo, 19(78), 58-67. doi:10.15421/nvlvet7812 (in Ukrainian).

Kotelevych, V.A. (2017). Ekologichni aspekty jakosti ta bezpeky harchovyh produktiv u Zhytomyrs'komu regioni. Visnyk ZhNAEU, 2(63), 123-127 (in Ukrainian).

Kotelevych V.A. (2017). Rol' organichnogo vyrobnyctva $\mathrm{u}$ formuvanni jakosti i bezpeky harchovoi' produkcii' u Zhytomyrs'komu regioni. Mizhnarodna naukovopraktychna konferencija "Organichne vyrobnyctvo i prodovol'cha bezpeka”, ZhNAEU, 169-172 (in Ukrainian).

Kotelevych, V.A. (2018). Jakist' ta prodovol'cha bezpeka tvarynnyc'koi' produkcii' v Zhytomyrs'komu regioni. Organichne vyrobnyctvo i prodovol'cha bezpeka. Zhytomyr: Vydavec' O.O. Jevenok, 255-261 (in Ukrainian).

Khimich, M.S., Gorobei, A.M., Kozulin, F.V., \& Zhekov, V.V. (2017). Monitoring of safety and quality products slaughter of pigs obtained in Odessa region. Scientific Messenger LNUVMBT named after S.Z. Gzhytskyj, 19(77), 148-152. doi:10.15421/nvlvet7732.

Ukaz prezydenta Ukrai'ny vid 15.06.2015. №951/2005 "Pro rishennja Rady nacional'noi' bezpeky i oborony Ukrai'ny pro zahody shhodo zabezpechennja vstupu Ukrai'ny do "Svitovoi' organizacii' torgivli" (in Ukrainian).

Jakubchak, O.M. (2011). Suchasni pidhody do zabezpechennja bezpechnosti m`jasa v Ukrai'ni. M jasni tehnologii' svtu, 7, 34-38 (in Ukrainian).

Jakubchak, O.M., Dyman', T.M., Olijnyk, L.V., \& Mazur, T.G. (2005). Metodychni rekomendacii' shhodo vprovadzhennja systemy NASSR na molokopererobnyh pidpryjemstvah. Kyi'v: Bioprom (in Ukrainian). 